\title{
Pengaruh Kualitas Layanan Terhadap Kepuasan Dan Loyalitas Nasabah Unit Simpan - Pinjam Bumdes Dana Merta Desa Tangkup Kabupaten Karangasem
}

\author{
Ni Komang Pani Yudiadari ${ }^{1}$ \\ Made Dian Putri Agustina ${ }^{2}$ \\ ${ }^{1,2}$ Fakultas Ekonomi, Bisnis, dan Pariwisata Universitas Hindu Indonesia \\ Email : yudiya.gempol@gmail.com
}

\begin{tabular}{|l|l|l|}
\hline Diterima: 8 Desember 2020 & Direvisi: 15 Desember 2020 & Disetujui: 20 Desember 2020 \\
\hline
\end{tabular}

\begin{abstract}
Service quality plays a very important role for the sustainability of a company, especially service companies such as Village-Owned Enterprises (BUMDes) Dana Merta in Karangasem Regency, Bali which is engaged in savings and loan business. The purpose of this study was to determine the effect of service quality on customer satisfaction and loyalty of BUMDesa Dana Merta savings and loans unit. The data collection method in this study used a questionnaire aimed at 162 respondents for further analysis using validity tests, reliability tests and path analysis. From the results of data analysis, the answers to the problems posed were obtained, namely (1) service quality has a positive and significant effect on customer loyalty, (2) service quality has a positive and significant effect on customer satisfaction, (3) customer satisfaction has a positive and significant effect on customer loyalty. , and (4) satisfaction mediates the effect of service quality on the loyalty of BUMDes Dana Merta savings and loan customers.
\end{abstract}

Keywords: service quality, customer satisfaction, customer loyalty.

\begin{abstract}
ABSTRAK
Kualitas layanan memegang peranan yang sangat penting bagi keberlangsungan suatu perusahaan terutama perusahaan jasa seperti Badan Usaha Milik Desa (BUMDes) Dana Merta di Kabupaten Karangasem, Bali yang bergerak dalam bidang usaha simpan pinjam. Tujuan dari penelitian ini adalah untuk mengetahui pengaruh kualitas layanan terhadap kepuasan dan loyalitas nasabah unit simpan pinjam BUMDesa Dana Merta. Metode pengumpulan data dalam penelitian ini menggunakan kuesioner yang ditujukan kepada 162 orang responden untuk selanjutnya dilakukan analisis dengan menggunakan uji validitas, uji reliabilitas dan analisis jalur (path analisys). Dari hasil analisis data, diperoleh jawaban atas permasalahan yang diajukan yaitu (1) kualitas layanan berpengaruh positif dan signifikan terhadap loyalitas nasabah, (2) kualitas layanan berpengaruh positif dan signifikan terhadap kepuasan nasahah, (3) kepuasan nasabah berpengaruh positif dan signifikan terhadap loyalitas nasabah, dan (4) kepuasan memediasi pengaruh kualitas layanan terhadap loyalitas nasabah simpan pinjam BUMDes Dana Merta.
\end{abstract}

Kata kunci : kualitas layanan, kepuasan nasabah, loyalitas nasabah.

\section{PENDAHULUAN}

Loyalitas pelanggan memegang peranan yang sangat vital bagi keberlangsungan hidup dan kesuksesan suatu perusahaan, baik itu manufaktur maupun jasa karena tanpa ada pelanggan yang 
loyal maka tidak akan ada bisnis. Loyalitas pelanggan mencerminkan niatan berperilaku (intended behavior) berkenaan dengan suatu produk atau jasa (Selnes, 2003). Pelanggan yang loyal atau setia adalah orang yang melakukan pembelian ulang dari perusahaan yang sama, serta memberikan informasi yang positif kepada pihak potensial lain dari mulut ke mulut (Sawitri et al 2013). Wendha et al (2013) mengemukakan bahwa agar pelanggan tetap loyal, maka perusahaan harus meyakinkan pelanggannya bahwa perusahaan tersebut mampu memberikan produk atau jasa yang bernilai secara terus menerus.

Bagi perusahaan jasa, kualitas layanan telah diakui sebagai salah satu faktor kunci keberhasilan perusahaan dalam menciptakan loyalitas. Choiriah dan Liana (2019) mendefinisikan pelayanan adalah upaya pemenuhan kebutuhan dan keinginan pelanggan serta ketepatan penyampaiannya untuk mengimbangi harapan pelanggan. Definisi kualitas layanan yang umum digunakan adalah tingkat di mana suatu pelayanan mampu memenuhi kebetuhan atau harapan pelanggan dan melibatkan perbandingan antara harapan dan kinerja aktual pelayanan yang dirasakan oleh pelanggan (Kumar dan Sikdar, 2014; Kusyana dan Pratiwi, 2019). Bukti pengaruh kualitas layanan secara positif dan signifikan terhadap loyalitas pelanggan telah dilaporkan oleh Dewi et al, (2014); Rakhmat dan Hidayat (2014), Michelle dan Siagian (2019), serta Thungasal dan Siagian (2019). Kualitas pelayanan juga telah terbukti secara luas sebagai salah satu faktor yang mampu menciptakan kepuasan pelanggan (Kusyana et al, 2020).

Thungsal (2019) mendefinisikan kepuasan sebagai "perasaan senang atau kecewa seseorang yang muncul setelah membandingkan antara kinerja (hasil) produk yang dipikirkan terhadap kinerja (atau hasil) yang diharapkan". Mempertahankan pelanggan yang loyal adalah sangat penting bagi banyak perusahaan terutama dalam kondisi persaingan yang ketat (Auka et al., 2013). Dalam dunia usaha yang semakin ketat, keunggulan kompetitif suatu perusahaan terletak pada kemampuan untuk menyampaikan layanan berkualitas tinggi agar dapat memenuhi harapan pelanggan yang pada akhirnya akan menciptakan kepuasan pelanggan, karena itu tidak dapat diragukan lagi pentingnya kualitas layanan bagi penyedia layanan di seluruh dunia (Allahham dan Aljumaa, 2014). Penelitian oleh Sulistyawati dan Smeinari (2015), Pratiwi dan Smeinari (2015), Dewi et al, (2014), Rahmat dan Hidayat (2014), Michelle dan Siagian (2019), serta Thungasal dan Siagian (2019) membuktikan bahwa kualitas layanan mampu menciptakan terjadinya kepuasan pelanggan. Shinta (2017 : 19) mengemukakan bahwa perusahaan perlu memperhatikan kepuasan pelanggan karena banyak manfaat yang akan diperoleh perusahaan, antara lain reputasi perusahaan menjadi postif, mendorong terciptanya loyalitas pelanggan, memungkinkan terciptanya word of mouth communication, dan meningkatkan keuntungan. Penelitian yang dilakukan oleh Dewi et al, 
(2014), Rakhmat dan Hidayat (2014), Michelle dan Siagian (2019), serta Thungasal dan Siagian (2019) membuktikan kepuasan berpengaruh positif dan signifikan terhadap loyalitas pelanggan.

Ketatnya persaingan yang kini terjadi di berbagai sektor industri juga berimbas pada lembaga-lembaga keuangan baik lembaga keuangan bank maupun non bank dan terjadi persaingan lintas sektor. Bank kini tidak hanya bersaing dengan sesama bank, namun juga dengan Badan Usaha Milik Desa (BUMDes) yang juga menawarkan produk berupa simpan pinjam kepada warga di desa tempat BUMDesa itu berdiri, sehingga bagi BUMDes yang bergerak dalam usaha simpan pinjam juga harus bersaing dengan lembaga keuangan bank yang tentu saja dikelola secara profesional dan persaingan tersebut bukan dalam kategori produk tapi juga kualitas pelayanan yang diberikan. Berdirinya BUMDes dilandasi oleh UU Nomor 32 Tahun 2004 tentang Pemerintahan Daerah Pasal 213 ayat (1) disebutkan bahwa "Desa dapat mendirikan badan usaha milik desa sesuai dengan kebutuhan dan potensi desa" dan tercantum pula dalam Peraturan Pemerintah (PP) Nomor 71 Tahun 2005 tentang Desa. Salah satu BUMDes yang ada di Bali adalah BUMDes Dana Merta yang terletak di Desa Tangkup, Kabupaten Karangasem yang merupakan salah satu sentra produksi kain tenun khas Sidemen. Sepanjang tahun 2018 jumlah simpanan di BUMDes Dana Merta setiap bulannya mengalami ketidak stabilan, tebukti pada bulan April jumlah tabungan mengalami penurunan yang signifikan hingga Rp. 21.426.521, namun pada bulan - bulan selanjutnya mengalami kenaikan yang siginifikan dan di bulan Agustus pemasukan mencapai Rp. 92.762.250. Dan juga dijelaskan bahwa tingkat kredit disetiap bulannya mengalami ketidak stabilan, pada bulan April kredit mengalami penurunan, namun pada bulan November kredit mengalami kenaikan hingga Rp. 22.689.886 dan kembali mengalami penurunan di bulan Desember.

Kualitas layanan merupakan kunci utama untuk menciptakan kepuasan dan loyalitas pelanggan (Said, 2017), sehingga sangat penting bagi BUMDes Dana Merta untuk menghadirkan layanan berkualitas tinggi kepada nasabahnya agar terus dapat berada di dalam persaingan. Tujuan dari peneltian ini adalah (1) mengetahui pengaruh kualitas layanan terhadap loyaltas nasabah, (2) m,engetahui pengaruh kualitas layanan terhadap kepuasan nasabah, (3) mengetahui pengaruh kepuasan terhadap loyalitas nasabah, dan (4) mengetahui peran kepuasan memediasi pengaruh kualitas layanan terhadap loyalitas nasabah BUMDes Dana Merta.

\section{TELAAH LITERATUR DAN HIPOTESIS}

\section{Telaah literatur}

\section{Kualitas layanan.}

Kualitas layanan dapat diukur dengan menggunakan dimensi Service Quality (ServQual), adalah suatu model pengukuran kualitas layanan yang telah diterima secara luas dan digunakan 
yang pertama kali dikembangkan oleh Parasuaraman et al pada tahun 1988. Model tersebut dianggap sebagai yang paling efisien dalam membantu suatu perusahaan untuk meningkatkan kualitas layanan (Kabadayi dan Cirpin, 2016). Parasuraman et al (1988) mengemukakan bahwa kualitas layanan dapat diukur menggunakan lima dimensi, di antaranya tangible/bukti fisik yang meliputi fasilitas fisik, peralatan, dan penampilan karyawan. Dimensi berikutnya adalah reliability/kehandalan yaitu kemampuan untuk melaksanakan janji secara akurat dan dapat dihandalkan, responsiveness/daya tanggap yaitu keinginan untuk menolong pelanggan and menyediakan pelayanan dengan cepat. Dimensi keempat adalah assurance/jaminan yaitu pengetahuan, kesopanan, dan kemampuan menciptakan rasa percaya pada pelanggan. Dimensi kelima adalah empathy.empati yaitu kepedulian dan perhatian individu yang diberikan oleh perusahaan kepada pelanggan.

\section{Kepuasan Pelanggan}

Dewi, et al (2014) menyatakan bahwa kepuasan pelanggan merupakan evaluasi setelah pembelian dimana produk yang dipilih sekurang - kurangnya sama atau melebihi harapan pelanggan, sedangkan ketidak puasan timbul apabila hasil (outcome) tidak memenuhi harapan. Beberapa pendapat mengenai defenisi kepuasan pelanggan diantaranya, Hardiyati (2010) yang mendefenisikan kepuasan pelanggan sebagai keseluruhan sikap yang ditunjukkan pelanggan atas barang atau jasa setelah mereka memperoleh dan menggunakannya. Hasil dari apa yang mereka harapkan dengan apa yang mereka dapatkan dari produk tersebut. Kepuasan adalah langkah yang penting dalam pembentukan loyalitas tetapi menjadi kurang signifikan ketika loyalitas mulai tibul melalui mekanisme-mekanisme lainnya. Mekanisme lainnya itu dapat berbentuk kebulatan tekad, dan ikatan social. Loyalitas Pelanggan

Loyalitas adalah suatu komitmen yang mendalam untuk melakukan pembelian ualng atau berlangganan suatu produk (jasa) secara konsisten di masa yang akan datang yang mengakibatkan terjadinya pembelian ulang atas merek yang sama meskipun terdapat pengaruh siruasi dan usahausaha pemasaran yang berpotensi menyebabkan tindakan pemindahan merek (Rakhmad \& Hidayat, 2014). Wendha et al (2019) melihat kepuasan pelanggan sebagai cerminan (reflection) gabungan Antara indikator niat, sikap dan performance penjual. Wendha et al (2019) mendefenisikan loyalitas pelanggan dengan melihat sejauh mana pelanggan tersebut melakukan pembelian ualng terhadap penyedia layanan, memperlihatkan sikap positif terhadap penyedia layanan dan akan menggunakan provider ini ketika kebutuhan akan layanan ini muncul.

\section{Hipotesis}


Berdasarkan telaah literatur dan kajian empiris yang dilakukan, maka hipotesis yang diajukan dalam penelitian ini adalah sebagai berikut :

H1 : Diduga Kualitas Layanan berpengaruh positif dan signifikan terhadap loyalitas nasabah

H2 : Diduga Kualitas Layanan berpengaruh positif dan signifikan terhadap kepuasan

H3 : Diduga Kepuasan berpengaruh positif dan signifikan terhadap Loyalitas Nasabah

H4 : Diduga Kualitas Layanan berpengaruh secara positif dan signifikan terhadap Loyalitas melalui Kepuasan

\section{METODE PENELITIAN}

\section{Desain Penelitian}

Penelitian ini adalah penelitian yang bersifat asosiatif atau penelitian yang mempelajari hubungan sebab akibat dengan tujuan untuk mengetahui pengaruh atau hubungan antara tiga variabel yaitu kualitas layanan sebagai variabel bebas, kepuasan sebagai variabel mediasi, dan loyalitas nasabah sebagai variabel terikat. Kerangka berpikir penelitian ini dpat dilihat pada Gambar 1 berikut ini :

\section{Gambar 1. Kerangka Berpikir}

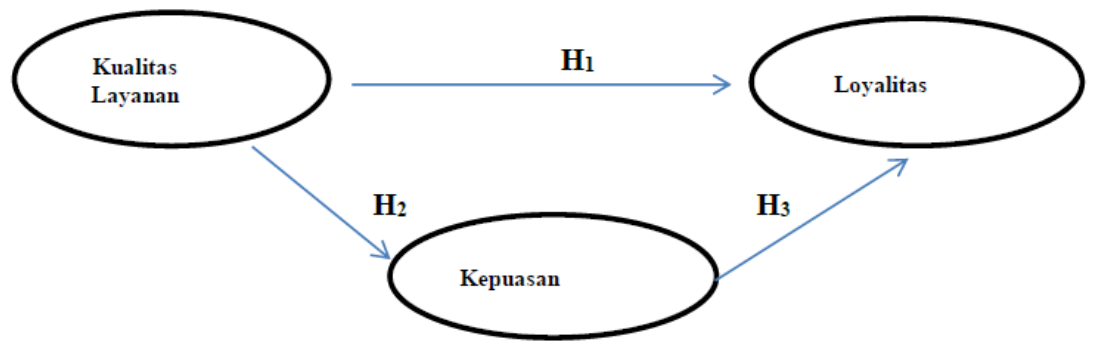

\section{Populasi dan Sampel}

Populasi

merupakan kumpulan dari semua elemen yang memiliki sejumlah karakteristik umum, terdiri atas himpunan untuk tujuan penelitian pemasaran (Micelle dan Siagian, 2019). Dalam penelitian ini yang menjadi populasi adalah nasabah BUMDes Dana Merta tahun 2018 yang jumlahnya 162 orang dan dalam penelitian ini menggunakan metode sensus yang artinya seluruh anggota populasi dilibatkan sebagai responden penelitian.

\section{Metode Pengumpulan Data}

Metode yang digunakan dalam pengumpulan data untuk penelitian ini antara lain observasi, wawancara, studi dokumentasi, studi pustaka, dan kuisioner. Pada metode kuisioner digunakan skala Likert dengan 5 (lima) pilihan jawaban yaitu sangat tidak setuju diberi bobot angka 1, tidak setuju diberi bobot angka 2, cukup setuju diberi bobot angka 3, setuju diberi bobot angka 4, dan sangat setuju diberi bobot 5 . Kuisioner terdiri atas total 29 item pernyataan dengan rincian 21 item pernyataan untuk mengukur kualitas layanan yang diadopsi dari Parasuraman et al (1988) serta Kusyana dan Pratiwi (2019), kepuasan dan loyalitas nasabah masing-masing 4 item pernyataan yang diadopsi dari Kusyana et al (2020). 


\section{Teknik Analisis Data}

1. Uji instrumen penelitian dilakukan dengan menggunakan uji validitas dan reliabilitas. Uji validitas bertujuan untuk memeriksan apakah kuisioner sebagai instrumen penelitian sudah tepat untuk mengukur apa yang seharusnya diukur (Sugiyono, 2014), sedangkan uji relibilitas adalah bertujuan untuk mencari tahu instrumen dalam penelitian yaitu kuisioner jika digunakan beberapa kali dalam mengukur obyek yang sama akan menghasilkan data yang sama (Sugiyono, 2014)

2. Analisis statistik deskriptif, yaitu suatu teknik yang digunakan dalam menganalisis data yang diperoleh dengan mendeskripsikan, menggambarkan dan menguraikan karakteristik setiap variabel yang diteliti.

3. Teknik analisis jalur (path analysis). Penelitian ini menggunakan teknik analisis data path analysis yang merupakan perluasan dari analisis regresi linear berganda dalam memperkirakan hubungan kausalitas antara yangtelah ditetapkan berdasarkan teori dan kajian empiris. Analisis jalur digunakan untuk menentukan hubungan 3 variabel atau lebih dalam mengkonfirmasi dan menolak hipotesis. Dasar perhitungan koefisien jalur adalah analisis korelasi dan regresi dan dalam perhitungannya dilakukan dengan bantuan software SPSS.

\section{HASIL DAN PEMBAHASAN}

\section{Uji Validitas}

Suatu kuisioner dikatakan vailid jika pernyataan pada kuesioner mampu untuk mengungkapkan sesuatu yang akan diukur oleh kuesioner tersebut. Uji validitas pada penelitian ini dilakukan terhadap variabel Kualitas layanan. Hasil uji coba disajikan pada Tabel 1. 


\section{Tabel 1}

Hasil Uji Validitas Variabel Kualitas Layanan

\begin{tabular}{|c|c|c|c|}
\hline No & Indikator & Koefisien Korelasi & Keterangan \\
\hline 1 & $\mathrm{X} 1.1$ & 0,725 & Valid \\
\hline 2 & $\mathrm{X} 1.2$ & 0,805 & Valid \\
\hline 3 & $\mathrm{X} 1.3$ & 0,786 & Valid \\
\hline 4 & $\mathrm{X} 1.4$ & 0,805 & Valid \\
\hline 5 & $\mathrm{X} 2.1$ & 0,810 & Valid \\
\hline 6 & $\mathrm{X} 2.2$ & 0,833 & Valid \\
\hline 7 & $\mathrm{X} 2.3$ & 0,859 & Valid \\
\hline 8 & $\mathrm{X} 2.4$ & 0,810 & Valid \\
\hline 9 & $\mathrm{X} 2.5$ & 0,832 & Valid \\
\hline 10 & $\mathrm{X} 3.1$ & 0,872 & Valid \\
\hline 11 & $\mathrm{X} 3.2$ & 0,877 & Valid \\
\hline 12 & $\mathrm{X} 3.3$ & 0,886 & Valid \\
\hline 13 & $\mathrm{X} 3.4$ & 0,894 & Valid \\
\hline 14 & $\mathrm{X} 4.1$ & 0,899 & Valid \\
\hline 15 & $\mathrm{X} 4.2$ & 0,840 & Valid \\
\hline 16 & $\mathrm{X} 4.3$ & 0,876 & Valid \\
\hline 17 & $\mathrm{X} 4.4$ & 0,901 & Valid \\
\hline 18 & $\mathrm{X} 5.1$ & 0,899 & Valid \\
\hline 19 & $\mathrm{X} 5.2$ & 0,899 & Valid \\
\hline 20 & $\mathrm{X} 5.3$ & 0,899 & Valid \\
\hline 21 & $\mathrm{X} 5.4$ & 0,899 & Valid \\
\hline
\end{tabular}

Sumber : data primer, diolah (2020)

Berdasarkan Tabel 1 diketahui bahwa seluruh indikator dalam variabel Kualitas Layanan memiliki koefisien korelasi yang lebih besar dari 0,30. Jadi dapat disimpulkan bahwa seluruh indikator telah memenuhi syarat validitas data. Berikutnya, pada Tabel 2 dapat diketahui hasil uji validitas terhadap variabel kepuasan nasabah.

Tabel 2

Hasil Uji Validitas Variabel Kepuasan Nasabah

\begin{tabular}{|c|c|c|c|}
\hline No & Indikator & Koefisien Korelasi & Keterangan \\
\hline 1 & M1 & 0,839 & Valid \\
\hline 2 & M2 & 0,838 & Valid \\
\hline 3 & M3 & 0,823 & Valid \\
\hline 4 & M4 & 0,816 & Valid \\
\hline
\end{tabular}

Sumber : data primer, diolah (2020)

Berdasarkan Tabel 2 diketahui bahwa seluruh indikator dalam variabel Kepuasan Nasabah memiliki koefisien korelasi yang lebih besar dari 0,30. Jadi dapat dikemukakan bahwa seluruh indikator telah memenuhi syarat validitas data. Uji validitas terhadap variabel terikat yaitu loyalitas nasabah dapat dilihat pada Tabel 3 berikut : 
Tabel 3

Hasil uji Validitas Variabel Loyalitas Nasabah

\begin{tabular}{|c|c|c|c|}
\hline No & Indikator & Koefisien Korelasi & Keterangan \\
\hline 1 & Y1 & 0,831 & Valid \\
\hline 2 & Y2 & 0,848 & Valid \\
\hline 3 & Y3 & 0,837 & Valid \\
\hline 4 & Y4 & 0,805 & Valid \\
\hline
\end{tabular}

Sumber : data primer, diolah (2020)

\section{Uji Reliabilitas}

Untuk mengukur reliabilitas dengan uji statistik cronbach alpha lebih besar dari 0,60. Hasil uji menunjukkan nilai cronbach alpha lebih besar dari 0,60 sehingga dapat dikatakan bahwa semua variabel adalah reliabel. Tabel 4 menunjukkan bahwa nilai cronbach's alpha adalah lebih besar 0,60 yang berarti telah memenuhi syarat relibilitas instrumen.

\section{Tabel 4}

\section{Hasil Uji Reliabilitas}

\begin{tabular}{|c|c|c|c|}
\hline No & Variabel & Nilai Alpha Cronbach & Keterangan \\
\hline 1 & Kualitas Layanan & 0,979 & Reliabel \\
\hline 2 & Kepuasan Nasabah & 0,848 & Reliabel \\
\hline 3 & Loyalitas Nasabah & 0,850 & Reliabel \\
\hline
\end{tabular}

Sumber : data primer, diolah (2020)

\section{Karakteristik Responden}

Dalam penelitian ini karakteristik responden digambarkan mengenai jenis kelamin, usia, penddikan dan intensitas kunjungan dalam satu bulan. Adapun karakteristik yang terkumpul melalui pengumpulan kuisioner adalah sebagai berikut :

Pada Tabel 5, dapat dinyatakan sebagai responden laki-laki sebanyak 92 orang (56,8\%) dan responden perempuan sebanyak 70 orang $(43,2 \%)$. Hal tersebut dikarenakan nasabah pada BUMDes Dana Merta Desa Tangkup, Kabupaten Karangasem lebih banyak didominasi laki-laki.

Tabel 5

Karakteristik Responden Menurut Jenis Kelamin

\begin{tabular}{|l|c|c|}
\hline Jenis Kelamin & $\begin{array}{c}\text { Jumlah } \\
\text { (Orang) }\end{array}$ & $\begin{array}{c}\text { Presentase } \\
\text { (\%) }\end{array}$ \\
\hline Laki- laki & 92 & 56,8 \\
\hline Perempuan & 70 & 43,2 \\
\hline Total & $\mathbf{1 6 2}$ & $\mathbf{1 0 0}$ \\
\hline
\end{tabular}

sumber : data primer, diolah (2019) 
Pada Tabel 6, dapat dinyatakan bahwa responden terbanyak adalah 36-45 tahun sebanyak 88 orang $(54,32 \%)$ disusul umur $26-35$ tahun sebanyak 56 orang $(34,57 \%)$ dan terendah ada pada umur diatas 45 tahun.

Tabel 6

Karakteristik Responden Menurut Usia

\begin{tabular}{|c|c|c|}
\hline Umur & $\begin{array}{c}\text { Jumlah } \\
\text { (Orang) }\end{array}$ & $\begin{array}{c}\text { Presentase } \\
\text { (\%) }\end{array}$ \\
\hline $17-25$ tahun & 15 & 9,26 \\
\hline $26-35$ tahun & 56 & 34,57 \\
\hline $36-45$ tahun & 88 & 54,32 \\
\hline$>45$ tahun & 3 & 1,85 \\
\hline Total & $\mathbf{1 6 2}$ & $\mathbf{1 0 0}$ \\
\hline
\end{tabular}

Sumber : data primer, diolah (2019)

Pada Tabel 7, dapat dinyatakan bahwa latar belakang pendidikan responden yang terbanyak adalah SMP/Sederajat sebanyak 76 orang $(46,91 \%)$, sedangkan responden dengan latar belakang pendidikan SMA/Sederajat adalah sebanyak 63 orang $(38,89 \%)$ dan terendah yaitu Diploma sebanyak 3 orang $(1,85 \%)$.

Tabel 7

Karakteristik Responden Menurut Pendidikan Terakhir

\begin{tabular}{|l|c|c|}
\hline Pendidikan Terakhir & $\begin{array}{c}\text { Jumlah } \\
\text { (Orang) }\end{array}$ & $\begin{array}{c}\text { Presentase } \\
(\%)\end{array}$ \\
\hline SD & 15 & 9,26 \\
\hline SMP & 76 & 46,91 \\
\hline SMA & 63 & 38,89 \\
\hline DIPLOMA & 3 & 1,85 \\
\hline STARTA 1 (S1) & 5 & 3,09 \\
\hline LAINNYA & 0 & 0 \\
\hline Total & $\mathbf{1 6 2}$ & $\mathbf{1 0 0}$ \\
\hline
\end{tabular}

Sumber : data primer, diolah (2019)

Pada Tabel 8, dapat dinyatakan bahwa responden lebih banyak berkunjung 1-10 kali dalam sebulan yaitu sebanyak 89 orang $(54,94 \%)$ dan terendah lebih dari 20 kali dalam sebulan yaitu sebanyak 5 orang $(3,09 \%)$.

Tabel 8

Karakteristik Responden Menurut Intensitas Kunjungan

\begin{tabular}{|l|c|c|}
\hline $\begin{array}{c}\text { Intensitas Kunjungan } \\
\text { (per bulan) }\end{array}$ & $\begin{array}{c}\text { Jumlah } \\
\text { (Orang) }\end{array}$ & $\begin{array}{c}\text { Presentase } \\
\text { (\%) }\end{array}$ \\
\hline $1-10 \mathrm{kali}$ & 89 & 54,94 \\
\hline $11-20 \mathrm{kali}$ & 68 & 41,97 \\
\hline$>20 \mathrm{kali}$ & 5 & 3,09 \\
\hline Total & $\mathbf{1 6 2}$ & $\mathbf{1 0 0}$ \\
\hline
\end{tabular}

Sumber : data primer, diolah (2019). 


\section{Deskripsi Jawaban Responden}

Pada bagian ini akan dideskripsikan jawaban responden beserta kriteria dari jawaban tersebut.

Tabel 9

Kriteria dan Penilaian Jawaban Kuisioner Variabel Kualitas Layanan

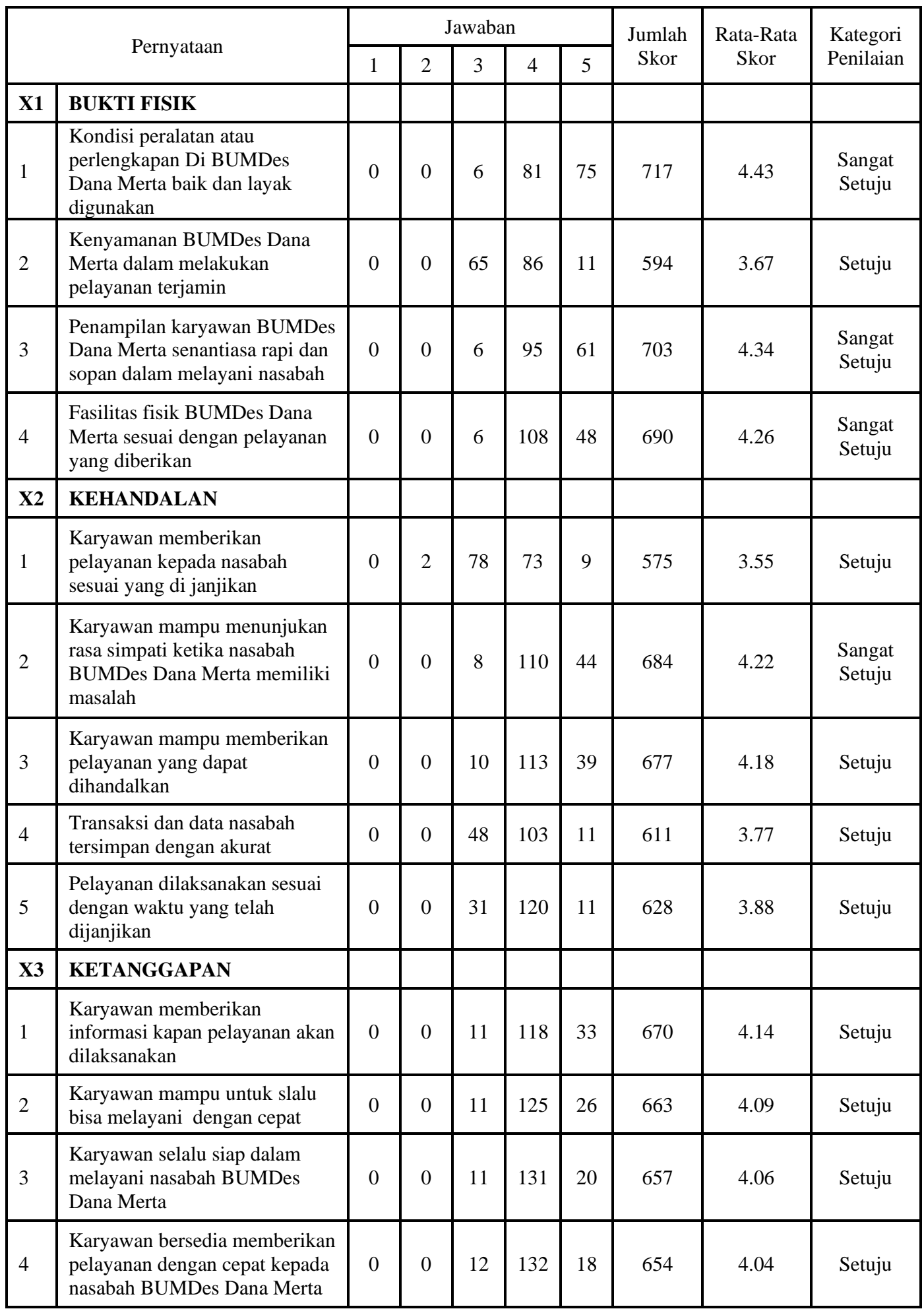




\begin{tabular}{|c|c|c|c|c|c|c|c|c|c|}
\hline $\mathrm{X} 4$ & JAMINAN & & & & & & & & \\
\hline 1 & $\begin{array}{l}\text { Karyawan memberikan rasa } \\
\text { percaya kepada nasabah }\end{array}$ & 0 & 0 & 13 & 133 & 16 & 651 & 4.02 & Setuju \\
\hline 2 & $\begin{array}{l}\text { Nasabah merasa aman } \\
\text { bertransaksi dengan BUMDes } \\
\text { Dana Merta }\end{array}$ & 0 & 0 & 27 & 124 & 11 & 632 & 3.9 & Setuju \\
\hline 3 & $\begin{array}{l}\text { Karyawan melayani nasabah } \\
\text { dengan sopan }\end{array}$ & 0 & 0 & 23 & 125 & 14 & 639 & 3.94 & Setuju \\
\hline 4 & $\begin{array}{l}\text { Perusahaan memberikan } \\
\text { dukungan dan kerja sama } \\
\text { terhadap nasabah }\end{array}$ & 0 & 0 & 14 & 133 & 15 & 649 & 4.01 & Setuju \\
\hline X5 & EMPATI & & & & & & & & \\
\hline 1 & $\begin{array}{l}\text { Karyawan memberikan } \\
\text { perhatian secara individu } \\
\text { kepada nasabah } \\
\end{array}$ & 0 & 0 & 14 & 134 & 14 & 648 & 4 & Setuju \\
\hline 2 & $\begin{array}{l}\text { Karyawan mengetahui produk } \\
\text { yang tepat sesuai kebutuhan } \\
\text { nasabah }\end{array}$ & 0 & 0 & 15 & 133 & 14 & 647 & 3.99 & Setuju \\
\hline 3 & $\begin{array}{l}\text { Karyawan mampu memberikan } \\
\text { pelayanan berkesan yang } \\
\text { memikat hati nasabah }\end{array}$ & 0 & 0 & 15 & 133 & 14 & 647 & 3.99 & Setuju \\
\hline 4 & $\begin{array}{l}\text { BUMDes Dana merta memiliki } \\
\text { jam operasional sesuai } \\
\text { ketentuan yang berlaku }\end{array}$ & 0 & 0 & 15 & 133 & 14 & 647 & 3.99 & Setuju \\
\hline \multicolumn{7}{|c|}{ Jumlah Skor } & 13683 & 651,6 & \multirow{2}{*}{ Setuju } \\
\hline \multicolumn{7}{|c|}{ Rata-rata Skor } & 84.46 & 4.02 & \\
\hline
\end{tabular}

Sumber : data primer, diolah (2019)

Berdasarkan Tabel 9, dapat diketahui dari seluruh pernyataan kuesioner untuk variabel kualitas layanan, rata-rata termasuk dalam kategori setuju. Nilai terendah diperoleh pernyataan X1.2.1 atau dari dimensi kehandalan sebesar 3,55. Pada dimensi kehandalan yang diterjemahkan dalam pernyataan tentang karyawan memberikan pelayanan kepada nasabah sesuai yang dijanjikan. Nilai tertinggi diperoleh dimensi bukti fisik yaitu pernyataan X1.1.1 dengan nilai ratarata sebesar 4,43 . Pernyataan pada item pernyataan tersebut kondisi peralatan atau perlengkapan di BUMDes Dana Merta baik dan layak digunakan. Nilai rata-rata dari keselurahan indikator variabel kualitas layanan sebesar 4,02. Berdasarkan nilai rata-rata tersebut nasabah menyatakan setuju terhadap keseluruhan pernyataan pada indikator - indikator variabel kualitas layanan tersebut. 
Tabel 10 Kriteria dan Penilaian Jawaban Kuisioner Variabel Kepuasan Nasabah

\begin{tabular}{|c|c|c|c|c|c|c|c|c|c|}
\hline \multirow{2}{*}{\multicolumn{2}{|c|}{ Pernyataan }} & \multicolumn{5}{|c|}{ Jawaban } & \multirow{2}{*}{$\begin{array}{l}\text { Jumlah } \\
\text { Skor }\end{array}$} & \multirow{2}{*}{$\begin{array}{l}\text { Rata- } \\
\text { Rata } \\
\text { Skor }\end{array}$} & \multirow{2}{*}{$\begin{array}{l}\text { Kategori } \\
\text { Penilaian }\end{array}$} \\
\hline & & 1 & 2 & 3 & 4 & 5 & & & \\
\hline 1 & $\begin{array}{l}\text { Pelayanan yang dirasakan } \\
\text { sesuai dengan harapan } \\
\text { nasabah (M1.1) }\end{array}$ & 0 & 0 & 14 & 91 & 57 & 691 & 4.27 & $\begin{array}{l}\text { Sangat } \\
\text { Setuju }\end{array}$ \\
\hline 2 & $\begin{array}{l}\text { Menjadi Nasabah BUMDes } \\
\text { Dana Merta adalah pilihan } \\
\text { tepat (M1.2) }\end{array}$ & 0 & 0 & 12 & 93 & 57 & 693 & 4.28 & $\begin{array}{l}\text { Sangat } \\
\text { Setuju }\end{array}$ \\
\hline 3 & $\begin{array}{l}\text { Secara keseluruhan pelayanan } \\
\text { yang diberikan oleh BUMDes } \\
\text { Dana Merta memuaskan } \\
\text { (M1.3) }\end{array}$ & 0 & 0 & 8 & 100 & 54 & 694 & 4.28 & $\begin{array}{l}\text { Sangat } \\
\text { Setuju }\end{array}$ \\
\hline 4 & $\begin{array}{l}\text { BUMDes Dana Merta } \\
\text { memberikan pelayanan yang } \\
\text { menyenangkan (M1.4) }\end{array}$ & 0 & 0 & 6 & 100 & 56 & 698 & 4.31 & $\begin{array}{l}\text { Sangat } \\
\text { Setuju }\end{array}$ \\
\hline \multicolumn{7}{|c|}{ Jumlah Skor } & 2776 & 694 & \multirow{2}{*}{$\begin{array}{l}\text { Sangat } \\
\text { Setuju }\end{array}$} \\
\hline & ta-rata Skor & & & & & & 17.14 & 4.28 & \\
\hline
\end{tabular}

Sumber : data primer, diolah (2019)

Berdasarkan Tabel 10, dapat dilihat dari seluruh pernyataan kuesioner rata-rata termasuk dalam kategori sangat setuju. Nilai terendah diperoleh pernyataan ke-1 (M1.1) sebesar 4,27. Pada indikator tersebut yang diterjemahkan dalam pernyataan tentang pelayanan yang dirasakan sesuai dengan harapan nasabah. Nilai tertinggi diperoleh pernyataan ke-4 (M1.4) dengan nilai rata-rata sebesar 4,31. Pernyataan pada indikator tersebut BUMDes Dana Merta memberikan pelayanan yang menyenangkan, nasabah sangat setuju dengan pernyataan tersebut. Berdasarkan nilai rata-rata tersebut nasabah menyatakan sangat setuju terhadap keseluruhan pernyataan pada indikator - indikator variabel kepuasan nasabah tersebut.

Tabel 11

Kriteria dan Penilaian Jawaban Kuisioner Variabel Loyalitas Nasabah

\begin{tabular}{|c|c|c|c|c|c|c|c|c|c|}
\hline \multirow{2}{*}{\multicolumn{2}{|c|}{ Pernyataan }} & \multicolumn{5}{|c|}{ Jawaban } & \multirow{2}{*}{$\begin{array}{l}\text { Jumlah } \\
\text { Skor }\end{array}$} & \multirow{2}{*}{$\begin{array}{l}\text { Rata- } \\
\text { Rata } \\
\text { Skor }\end{array}$} & \multirow{2}{*}{$\begin{array}{l}\text { Kategori } \\
\text { Penilaian }\end{array}$} \\
\hline & & 1 & 2 & 3 & 4 & 5 & & & \\
\hline 1 & $\begin{array}{l}\text { BUMDes Dana Merta sebagai } \\
\text { pilihan utama untuk bertransaksi } \\
\text { / melakukan kredit (Y1.1) }\end{array}$ & 0 & 0 & 10 & 87 & 65 & 703 & 4.34 & $\begin{array}{l}\text { Sangat } \\
\text { Setuju }\end{array}$ \\
\hline 2 & $\begin{array}{l}\text { Saya akan merekomendasikan } \\
\text { BUMDes Dana Merta kepada } \\
\text { orang lain (Y1.2) }\end{array}$ & 0 & 0 & 10 & 86 & 66 & 704 & 4.35 & $\begin{array}{l}\text { Sangat } \\
\text { Setuju }\end{array}$ \\
\hline 3 & $\begin{array}{l}\text { Saya akan menceritakan hal - hal } \\
\text { positif mengenai BUMDes Dana } \\
\text { Merta kepada orang lain (Y1.3) }\end{array}$ & 0 & 0 & 6 & 80 & 76 & 718 & 4.43 & $\begin{array}{l}\text { Sangat } \\
\text { Setuju }\end{array}$ \\
\hline 4 & $\begin{array}{l}\text { Saya akan tetap melakukan } \\
\text { transaksi di BUMDes Dana } \\
\text { Merta pada masa yang akan } \\
\text { datang (Y1.4) }\end{array}$ & 0 & 0 & 6 & 91 & 65 & 707 & 4.36 & $\begin{array}{l}\text { Sangat } \\
\text { Setuju }\end{array}$ \\
\hline \multicolumn{7}{|c|}{ Jumlah Skor } & 2832 & 708 & Sangat \\
\hline \multicolumn{7}{|c|}{ Rata-rata Skor } & 17.48 & 4.37 & Setuju \\
\hline
\end{tabular}

Sumber : data primer, diolah (2019) 
Berdasarkan Tabel 11, dapat dilihat dari pernyataan kuesioner rata-rata termasuk dalam kategori sangat setuju. Satu-satunya pernyataan yang memiliki kategori baik sekaligus menjadi nilai tertinggi diperoleh pernyataan ke-3 (Y1.3) sebesar 4,43. Pada indikator tersebut yang diterjemahkan dalam pernyataan saya akan menceritakan hal-hal positif mengenai BUMDes Dana Merta kepada orang lain. Nilai rata-rata dari keselurahan indikator variabel loyalitas nasabah sebesar 4,37. Berdasarkan nilai rata-rata tersebut nasabah menyatakan sangat setuju terhadap keseluruhan pernyataan pada indikator - indikator variabel loyalitas nasabah tersebut

\section{Analisis Jalur}

Pengujian data pada penelitian ini menggunakan analisis jalur (path analysis) guna menguji pola hubungan yang mengungkapkan pengaruh variabel atau seperangkat variabel terhadap variabel lainnya, baik pengaruh langsung maupun pengaruh tidak langsung.

\section{Gambar 2}

\section{Model Jalur Hubungan Kualitas Layanan Terhadap Kepuasan Dan Loyalitas Nasabah BUMDes Dana Merta Desa Tangkup, Kabupaten Karangasem}

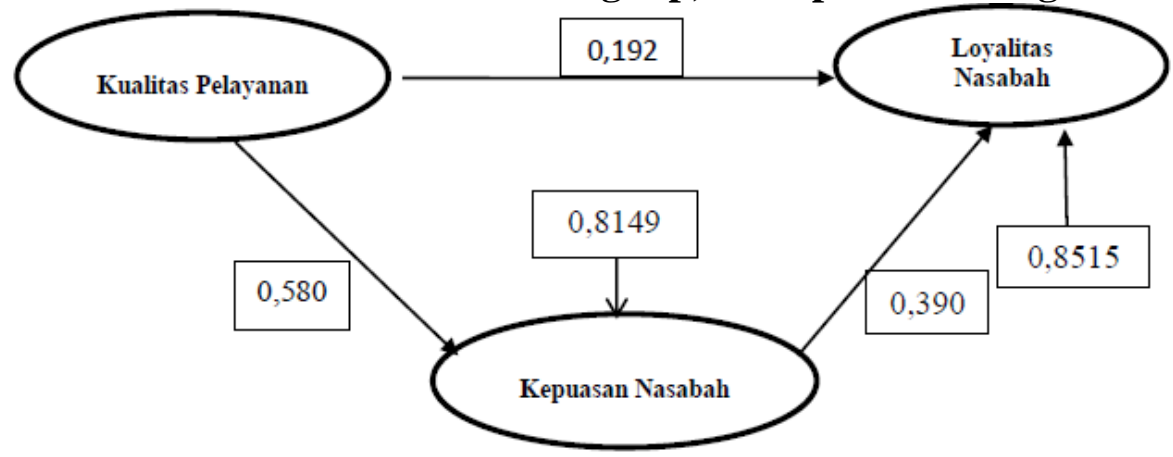

Berdasarkan Gambar 2 maka dapat dihitung besarnya pengaruh langsung, pengaruh tidak langsung, dan pengaruh total antar variabel sebagai berikut :

Tabel 12

Pengaruh Langsung, Tidak Langsung, dan Pengaruh Total

\begin{tabular}{lcccc}
\hline Variabel & $\begin{array}{c}\text { Pengaruh } \\
\text { langsung }\end{array}$ & $\begin{array}{c}\text { Pengaruh tidak } \\
\text { langsung melalui } \\
\text { Kepuasan nasabah }\end{array}$ & $\begin{array}{c}\text { Pengaruh } \\
\text { total }\end{array}$ \\
\hline $\begin{array}{l}\text { Kualitas } \\
\text { layanan } \\
\text { Kualitas } \\
\text { layanan }\end{array}$ & $\begin{array}{c}\text { Loyalitas } \\
\text { nasabah } \\
\text { Kepuasan }\end{array}$ & 0,192 & 0,226 & 0,418 \\
Kepuasan & nasah & 0,580 & & 0,580 \\
\hline
\end{tabular}

Sumber : data primer, diolah (2019) 
Dari Tabel 12 maka dapat dikemukakan hasil analisis jalur dalam menguji hipotesis adalah sebagai berikut :

1. Pengaruh kualitas layanan terhadap loyalitas nasabah. Berdasarkan hasil perhitungan diperoleh taraf signifikansi penelitian untuk variabel kualitas layanan terhadap loyalitas nasabah sebesar $0,022<0,05$; di mana nilai thitung $(2,316)>t_{\text {tabel }}(1,975)$ sehingga $\mathrm{H} 0$ ditolak dan H1 diterima, dengan kata lain kualitas layanan berpengaruh positif dan signifikan terhadap loyalitas nasabah pada BUMDes Dana Merta Desa Tangkup, Kabupaten Karangasem. Hasil mendukung penelitian yang dilakukan Dewi et al, (2014); Rakhmat dan Hidayat (2014), Michelle dan Siagian (2019), serta Thungasal dan Siagian (2019)

2. Pengaruh Kualitas Layanan terhadap Kepuasan nasabah. Berdasarkan hasil perhitungan diperoleh taraf signifikansi penelitian untuk variabel kualitas layanan terhadap kepuasan nasabah sebesar $0,000<0,05$; dengan nilai thitung $(9,004)>t_{\text {tabel }}(1,975)$ sehingga $\mathrm{H} 0$ ditolak dan $\mathrm{H} 2$ diterima, dengan kata lain kualitas layanan berpengaruh positif dan signifikan terhadap kepuasan nasabah pada BUMDes Dana Merta Desa Tangkup, Kabupaten Karangasem. Hasil ini mendukung penelitian yang dilakukan oleh Sulistyawati dan Smeinari (2015), Pratiwi dan Smeinari (2015), Dewi et al, (2014), Rahmat dan Hidayat (2014), Michelle dan Siagian (2019), serta Thungasal dan Siagian (2019) yang juga membuktikan kualtas layanan berpengaruh positif dan signifikan terhadap kepuasan.

3. Pengaruh kepuasan terhadap loyalitas nasabah. Berdasarkan hasil perhitungan diperoleh taraf signifikansi penelitian untuk variabel kepuasan nasabah terhadap loyalitas nasabah sebesar 0,000 $<0,05$; dengan nilai $t_{\text {hitung }}(4,703)>\mathrm{t}_{\text {tabel }}(1,975)$ sehingga $\mathrm{H} 0$ ditolak dan $\mathrm{H} 3$ diterima, dengan kata lain kepuasan nasabah berpengaruh positif dan signifikan terhadap loyalitas nasabah pada BUMDes Dana Merta Desa Tangkup, Kabupaten Karangasem. Hasil penelitian ini mendukung penelitian yang dilakukan oleh Dewi et al, (2014), Rakhmat dan Hidayat (2014), Michelle dan Siagian (2019), serta Thungasal dan Siagian (2019) yang juga membuktikan kepuasan berpengaruh positif dan signifikan terhadap loyalitas.

4. Peran kepuasan memediasi pengaruh kualitas layanan terhadap loyalitas nasabah. Berdasarkan hasil perhitungan diperoleh ZhitungX $(4,195)>$ Ztabel $(1,96)$ dengan demikian kepuasan nasabah dapat memediasi hubungan antara kualitas layanan terhadap loyalitas nasabah pada BUMDes Dana Merta Desa Tangkup, Kabupaten Karangasem. 


\section{SIMPULAN DAN SARAN}

\section{Simpulan}

Berdasarkan hasil analisis data dan pembahsan, maka dapat disimpulkan sebagai berikut:

1. Berdasarkan hasil perhitungan diperoleh tarif signifikan peneliatan untuk variabel Kualitas Layanan terhadap Loyalitas Nasabah sebesar 0,022 $<0,05$,nilai thitung $=2,316$ lebih besar dari ttabel = 1,975, sehingga $\mathrm{H} 0$ ditolak dan $\mathrm{H} 1$ diterima, dengan kata lain Kualitas Layanan berpengaruh positif dan signifikan terhadap Loyalitas Nasabah pada BUMDes Dana Merta Desa Tangkup, Kabupaten Karangasem. Hasil tersebut berarti bahwa kualitas layanan dapat mendorong terjadinya loyalitas nasabah pada BUMDes Dana Merta Desa Tangkup, Kabupaten Karangasem.

2. Berdasarkan hasil perhitungan diperoleh tarif signifikan peneliatan untuk variabel Kualitas Layanan terhadap Kepuasan Nasabah sebesar 0,000 $<0,05$, nilai thitung = 9,004 lebih besar dari ttabel = 1,975, sehingga H0 ditolak dan H1 diterima, dengan kata lain Kualitas Layanan berpengaruh positif dan signifikan terhadap Kepuasan Nasabah pada BUMDes Dana Merta Desa Tangkup, Kabupaten Karangasem. Hasil tersebut berarti bahwa kualitas pelayanan dapat mendorong terjadinya kepuasan pada BUMDes Dana Merta Desa Tangkup, Kabupaten Karangasem.

3. Berdasarkan hasil perhitungan diperoleh tarif signifikan peneliatan untuk variabel Kepuasan Nasabah terhadap Loyalitas Nasabah sebesar 0,000 0,05 , nilai thitung $=4,703$ lebih besar dari ttabel = 1,975, sehingga H0 ditolak dan H1 diterima, dengan kata lain Kepuasan Nasabah berpengaruh positif dan signifikan terhadap Loyalitas Nasabah pada BUMDes Dana Merta Desa Tangkup, Kabupaten Karangasem. Hal tersebut berarti bahwa kepuasan nasabah dapat mendorong loyalitas nasabah pada BUMDes Dana Merta Desa Tangkup, Kabupaten Karangasem

4. Berdasarkan hasil perhitungan diperoleh Nilai Zhitung $(4,195)>$ Ztabel $(1,96)$ dengan demikian Kepuasan Nasabah dapat berperan dalam memediasi pengaruh antara Kualitas Layanan terhadap Loyalitas Nasabah pada BUMDes Dana Merta Desa Tangkup, Kabupaten Karangasem. Hasil ini mendukung penelitian yang dilakukan oleh Huili danYing (2012), Jiewanto et al, (2012), dan Ganic et al (2018) yang membuktikan kepuasan memediasi pengaruh kualitas layanan terhadap loyalitas.

\section{Saran}

Berdasarkan hasil simpulan, maka dapat disarankan sebagai berikut: 
1. Penulis menyarankan BUMDes Dana Merta Desa Tangkup, Kabupaten Karangasem untuk selalu memperhatikan kualitas layanan agar sesuai dengan harapan dan kebutuhan nasabah untuk menjaga kepuasan nasabah dengan cara memaksimalkan kinerja karyawan.

2. Penulis menyarankan BUMDes Dana Merta Desa Tangkup, Kabupaten Karangasem menjaga hubungan baik dengan nasabah dengan meningkatkan kualitas pelayanan sehingga nasabah merasa puas dan loyal sehingga memperbesar kemungkinan adanya nasabah baru dengan cara karyawan harus melayani nasabah dengan baik dan ramah.

3. Diharapkan BUMDes Dana Merta Desa Tangkup, Kabupaten Karangasem memiliki karyawan-karyawan yang handal sehingga dapat menjaga reputasi dan citra perusahaan dan dapat dipercaya oleh nasabah.

\section{DAFTAR PUSTAKA}

Allahham, A., dan A. Aljumaa. 2014. Analyzing Antecedents of Customer Satisfaction and its Impact on Word of Mouth Communication in Life Insuranjce Services. International Journal of Management Sciences and Business Research, Vol. 3, Issue 4.

Auka, D., Bosire, J. N., \& Matern, V. (2013). Perceived service quality and customer loyalty in retail banking in Kenya. British Journal of Marketing Studies, Vol. 1, No. 3, pp. 32-61

Benni Kusyana, Dewa Nyoman dan Pratiwi, Komang Ary, 2019. Skala Pengukuran Kualitas Layanan : Sebuah Kajian Literatu, Jurnal Widya Manajemen Vol. 1, No. 2, Agustus 2019.

Choiriah, Eka Ni'matul dan Liana, Lie, 2019. Pengaruh Kualitas Produk, Citra Merk, dan Kualitas Layanan Terhadap Loyalitas Pelanggan di Mediasi Kepuasan Pelanggan (Studi pada Pelanggan Sepeda Motor Honda di Kota Semarang)

Ganic, E., V. B. Hodovic., dan M. A. Kalajdzic. 2018. Effects of Servperf Dimension on Students Loyalty-Do You Know What is Behind the Scene. International Journal of Business and Social Science, Vol. 9, No. 2.

Hardiyati, Ratih, 2010. Analisis Pengaruh Kualitas Pelayanan Terhadap Kepuasan Konsumen Menggunakan Jasa Penginapan (Villa) Agrowisata Kebun Teh Pagilaran. Semarang

Hidayat, Deddy Rakhmad dan Firdaus, Muhammad Riza, 2014. Analisis Pengaruh Kualitas Layanan, Harga, Kepercayaan, Citra Perusahaan, Dan Kepuasan Pelanggan Terhadap Loyalitas Pelanggan:(Studi Pada Pelanggan Telkom Speedy Di Palangka Raya)

Huili, Y. dan Y. Jing. 2012. Empirical Research and Model Building About Customer Satisfaction Index on Postgraduate Education Service Quality. Canadian Social Science, Vol. 8 No. 1, pp. 108-111.

Jiewanto, A., Laurens, C. dan L. Nelloh. 2012. Influence of Service Quality, University Image, and Student Satisfaction toward WOM Intention: A Case Study on Universitas Pelita Harapan Surabaya. Procedia - Social and Behavioral Sciences, Vol. 40, pp. 16 - 23 
Kabadayi, N., dan B. G. Cirpin. 2016. Service Quality Analysis Using a Fuzzy AHP Methodology : A Case Study in Veterinary Hospital in Turkey. International Conference on Industrial Engineering and Operations Management. USA, September 23-23, 2016

Kumar, A., dan P. Sikdar. 2014. Retail Service Quality Assessment-A Scale Validation Study In Indian Perspective. AIMA Journal of Management and Research, Vol. 8, Issue1/4.

Kusuma Dewi, Gusti Ayu Putu Ratih et al, 2014. Pengaruh Kualitas Pelayanan Terhadap Kepuasan Dan Loyalitas Nasabah PT. BPR Hoki Di Kabupaten Tabanan.

Kusyana, D.N.B., P.A. Purwaningrat., dan M.P. Sunny. 2020. Peran Kualitas Layanan Dalam Menciptakan Loyalitas Mahasiswa. Jurnal Widya Manajemen, Vol. 2, No. 1, Hal. 10-27

Michelle dan Siagan,Hotlan, 2019. Pengaruh Kualitas Layanan Dan Fasilitas Terhadap Loyalitas Pelanggan Melalui Kepuasan Pelanggan Melalui Kepuasan Pelanggan Café Zybrick \& Catina.

Parasuraman, A.P., L.L. Berry, dan V. A. Zeithaml. 1988. SERVQUAL : A Multiple Item Scale for Measuring Consumer Perceptions of Service Quality. Journal of Retailing, Vol. 64, No. 1

Shinta, A. 2017. Manajemen Pemasaran. Unversitas Brawijaya Press.

Thungasal, Eddy dan Siagian, M.Sc, Dr. Ir. Hotlan, 2019. Pengaruh Kualitas Layanan dan Harga Terhadap Loyalitas Pelanggan Melalui Kepuasan Pelanggan pada Hotel Kasuari

Wendha,A.A Ayu Atika Paramitha, et al, 2013. Pengaruh Kualitas Layanan Terhadap Kepuasan dan Loyalitas Pelanggan Garuda Indonesia di Denpasar. 